\title{
FGF6 wt Allele
}

National Cancer Institute

\section{Source}

National Cancer Institute. FGF6 wt Allele. NCI Thesaurus. Code C51501.

Human FGF6 wild-type allele is located within 12p13 and is approximately $11 \mathrm{~kb}$ in length.

This allele, which encodes fibroblast growth factor 6 protein, is involved in mitogenesis

and angiogenesis. Aberrant allelic activity was capable of oncogenic transforming activity when transfected into mammalian cells. 